\title{
INNOVATIVE HEALTH PARTNERSHIPS
}

The Diplomacy of Diversity 
This page intentionally left blank 


\title{
GLOBAL HEALTH DIPLOMACY - Vol. 1
}

\section{INNOVATIVE HEALTH PARTNERSHIPS}

The Diplomacy of Diversity

\author{
Edited by \\ Daniel Low-Beer \\ Switzerland
}


Published by

World Scientific Publishing Co. Pte. Ltd.

5 Toh Tuck Link, Singapore 596224

USA office: 27 Warren Street, Suite 401-402, Hackensack, NJ 07601

UK office: 57 Shelton Street, Covent Garden, London WC2H 9HE

\section{British Library Cataloguing-in-Publication Data}

A catalogue record for this book is available from the British Library.

Front cover images by John Rae.

\section{Global Health Diplomacy - Vol. 1 INNOVATIVE HEALTH PARTNERSHIPS \\ The Diplomacy of Diversity}

Copyright (C) 2012 by World Scientific Publishing Co. Pte. Ltd.

All rights reserved. This book, or parts thereof, may not be reproduced in any form or by any means, electronic or mechanical, including photocopying, recording or any information storage and retrieval system now known or to be invented, without written permission from the Publisher.

For photocopying of material in this volume, please pay a copying fee through the Copyright Clearance Center, Inc., 222 Rosewood Drive, Danvers, MA 01923, USA. In this case permission to photocopy is not required from the publisher.

ISBN-13 978-981-4366-14-4

ISBN-10 981-4366-14-5

Typeset by Stallion Press

Email: enquiries@stallionpress.com

Printed in Singapore. 


\section{Contents}

List of Authors $\quad$ ix

Acknowledgements xiii

Abbreviations $\quad \mathrm{xv}$

Introduction and... The Health Diplomacy of Diversity 1

Daniel Low-Beer

Section 1 Common Themes 29

1 Origins and Diversity of Health Partnerships 31

Richard Manning

2 Negotiating with New Partners to Increase the Effectiveness 55 and Volume of Aid: The Role of Global Funds

Paul Isenman and Alexander Shakow

3 Managing Health Partnerships At Country Level Hareya Fassil and Tedros Adhanom Ghebreyesus

4 Managing for Results: A “Common Currency" to

Coordinate Health Development

Daniel Low-Beer

5 Country Health Systems and Global Health Partnerships:

What are the Challenges, How to Think about Them

and What to Do Differently

Dean Shuey and Rebecca Dodd 
6 Limitations of Partnerships: Taking the Agenda Forward Margret Thalwitz

\section{Section 2 Integrating New Partnerships at Global Level}

7 Global Health Programmes: Negotiating Aid Effectiveness into New Partnerships

Prerna Banati and Daniel Low-Beer

8 Malaria: Partnerships in Malaria Control

Bernard L. Nahlen and Richard W. Steketee

9 Innovative Approaches to Financing Development:

The GAVI Alliance

Bjorg Sandkjaer

10 PEPFAR: A Results-Driven Approach to International HIV Support

Katherine Marconi, Paul Bouey and Mark Dybul

11 Private Foundations: Their Role in Financing and Health Governance

Nina Ingenkamp and Daniel Low-Beer

12 Private Sector: New Ways of Doing Business

Dida Connor, David Evans and Brian Brink

13 Civil Society Partners: Claiming Spaces for Civil Society in Global Health Josh Galjour and Asia Russell

\section{Section 3 Integrating New Partnerships at Country Level}

14 Governance and Sustainable Financing in Southern Africa: Swaziland, a Case Study

Alan Whiteside

15 Negotiating Aid Reform in Viet Nam: Unpacking "Country" 403 Ownership Rebecca Dodd and Jean-Marc Olivé 
16 Ethiopia: Aligning Stakeholders Behind National

Health Plans

W Lemma, N Kedir, G Azene, B Abdosh,

$J$ Aliy and $O$ Bushen

17 India: Scaling HIV Prevention Through Partnerships - The

Avahan Experience

Aparajita Ramakrishnan, Sema K. Sgaier

and Ashok Alexander

18 Russia: Key Characteristics of the NGO AIDS

Response: Assertive Leadership, Professional Reputation, and Broad Partnerships

Alexey Bobrik

19 State Fragility: Working with Partners to Achieve Health

Results in African Countries

Erling $H \phi g$

20 Health Communities: Social Capital and Effective

Partnerships - Building on Community Responses

Daniel Low-Beer

Conclusions - Towards an Innovative Global Health

Partnership

Daniel Low-Beer

Appendix of Additional Study Resources

Index 
This page intentionally left blank 


\section{List of Authors ${ }^{1}$}

Daniel Low-Beer — is Director of Performance, Impact \& Effectiveness at the Global Fund to Fight AIDS, TB and Malaria. He has worked with WHO, ministries of health and NGOs.

Richard Manning - was Chair of the OECD Development Assistance Committee, Director General of Policy at DFID and chair of the Replenishment of the Global Fund. He has played a leading role in development, health and the replenishments of World Bank and Innovative Health Partnerships.

Paul Isenman - is an independent consultant on aid architecture and effectiveness. He held senior positions in the World Bank and OECD. He was one of the principal architects of the Paris Declaration on aid effectiveness.

Alexander Shakow - has spent over 50 years working on development issues. He held senior positions in the US Peace Corps, USAID and the World Bank. Now retired, he is an occasional independent consultant for international agencies.

Minister Tedros Adhanom Ghebreyesus — is Minister of Health, Federal Democratic Republic of Ethiopia and has been chair of the Roll Back Malaria Partnerships and the Global Fund. He has been a major voice in strengthening the country ownership of development aid.

\footnotetext{
${ }^{1}$ The findings and views are those of the authors and do not necessarily represent those of the affiliate institution.
} 
Hareya Fassil — is international affairs advisor to the Minister of Health of Ethiopia.

Dean Shuey - has worked for both non-governmental organizations and the World Health Organization at field, national and regional level in both Africa and Asia.

Rebecca Dodd - works at the Western Pacific Regional Office of the World Health Organisation in Manila, She previously worked at WHO country office in Vietnam, and has written extensively on health partnerships and health governance.

Margret Thalwitz - was director of Global Programs and Partnerships for the World Bank. She helped lead the World Bank's work with innovative health partnerships and the Accra Action Agenda.

Prerna Banati - is Takemi Fellow in Global Health and Population at Harvard University.

Bernard Nahlen - is deputy coordinator of the United States President's Malaria Initiative (PMI).

Richard Stekete - is responsible for the malaria control and evaluation partnership in Africa (MACEPA), for Path. He was chair of the Monitoring, Evaluation, Reference Group of RBM.

Bjorg Sandkjaer - is senior programme officer, Public Policy, GAVI Alliance.

Kathy Marconi - was director of Strategic Information at PEPFAR. She is Professor and Director of Health Care Administration at University of Maryland University College.

Paul Bouey - is director of Strategic Information at PEPFAR and leads their approach to results.

Mark Dybul - was the US Global AIDS Coordinator in charge of PEPFAR and works in HIV, malaria, and global health as co-director at Georgetown's Institute for National and Global Health Law.

Nina Ingenkamp — is technical officer at the Global Fund for AIDS, TB and malaria. 
Dida Connor - is a senior private-sector officer at the Global Fund for AIDS, TB and malaria.

David Evans - is manager, private-sector resource mobilisation at the Global Fund.

Brian Brink - is chief medical officer of Anglo-American plc. and lives in South Africa.

Josh Galjour - is Program Officer at the Global Fund to Fight AIDS, Tuberculosis and Malaria. He has worked with civil society organizations in the U.S. and sub-Saharan Africa, and his research interests include the governance of global health.

Asia Russell - is Director of International Policy at Health GAP (Global Access Project) and is a leading community activist in AIDS and global health. From 2007-2009, she represented Developed Country NGOs on the Board of Directors of the Global Fund to Fight AIDS, Tuberculosis and Malaria.

Alan Whiteside - is the Director of the Health Economics and HIV/ AIDS Research Division at the University of KwaZulu-Natal. He was Commissioner of the UN Commission on HIV/AIDS and Governance in Africa. He has been working on issues of HIV AIDS since 1987. His most recent book 'HIV/AIDS: A very Short Introduction' was published by Oxford University Press in 2008.

Jean-Marc Olivé — is a medical doctor and public health specialist. He spent more than 30 years at the World Health Organization, serving in The Caribbean, Latin America, Africa, Europe and Asia. His last post was as WHO Representative in Vietnam.

Wuleta Lemma (with N. Kedir, G. Azene, B. Abdosh, J. Aliy) - is Assistant Professor, Country Director, Tulane Ethiopia Program and Director, Center for Global Health Equity, Tulane University, USA. N. Kedir is the former Director General, Policy, Planning \& Finance (PPF) Directorate, Federal Ministry of Head Ethiopia. G. Azen, B. Abdosh and J. Aliy are Senior Experts and Heads of programs at the Tulane University Technical Assistant Program, Ethiopia. 
Aparajita Ramakrishnan (with S. Sgaier, A. Alexander) — is a senior programme officer with the Bill \& Melinda Gates Foundation. Sema Sgaier is a programme officer. Ashok Alexander is the head of the India Office of the Bill \& Melinda Gates Foundation.

Alexey Bobrik - is director of the Open Health Institute in Russia and pioneer of the NGO response.

Erling Hog — is at the London School of Economics and Political Sciences, specializing in fragile states. 


\section{Acknowledgements}

This book is dedicated to Ann and Tom Low-Beer, and to their love of health, education, debate and books.

Special thanks to Eve, Louis and Noah Low-Beer for their wonderful support, stimulation and distractions while writing the book, Ann Low-Beer for patiently discussing and shaping the ideas and language, Andrew Cassels for his guidance on several chapters, John Rae for the fitting cover photos, and Elena Nash and V.K. Sanjeed for their excellent editorial support. 
This page intentionally left blank 


\title{
Abbreviations
}

\author{
AIDS \\ acquired immune deficiency syndrome \\ ART \\ antiretroviral therapy or treatment \\ DALY \\ disability-adjusted life year \\ DFID \\ Department for International Development (United \\ Kingdom) \\ FDI \\ foreign direct investment \\ G8 \\ group of eight nations (Canada, France, Germany, Italy, \\ Japan, the United Kingdom, the United States and \\ Russia) \\ G20 \\ group of twenty nations (G8 and Argentina, Australia, \\ Brazil, China, India, Indonesia, Mexico, Saudi Arabia, \\ South Korea and Turkey) \\ GAVI Alliance Global Alliance for Vaccines and Immunisation \\ GDP \\ gross domestic product \\ HIV \\ human immunodeficiency virus \\ IAVI \\ IMF \\ International AIDS Vaccine Initiative \\ International Monetary Fund \\ MDG \\ Millennium Development Goal \\ MSF \\ Medecins Sans Frontieres \\ NGO \\ nongovernmental organisation \\ ODA \\ official development assistance \\ OECD \\ Organisation for Economic Co-operation and \\ Development
}


PEPFAR United States President's Emergency Plan for AIDS Relief

TB tuberculosis

UNAIDS Joint United Nations Programme on HIV/AIDS UNDP United Nations Development Programme UNICEF United Nations International Children's Fund USAID United States Agency for International Development WHA World Health Assembly

WHO

World Health Organisation 